\title{
Hydrogeochemistry of Thermal Waters of Baransky Volcano, Iturup Island (Southern Kurils)
}

\author{
I. V. Bragin1, G. A. Chelnokov1, R. V. Zharkov², 0. V. Chudaev1, N. A. Kharitonova1,3 \\ ${ }^{1}$ Far East Geological Institute, Far Eastern Branch of Russian Academy of Sciences, Vladivostok, Russia \\ ${ }^{2}$ Insitute of Marine Geology and Geophysics, Far Eastern Branch of Russian Academy of Sciences, \\ Yuzhno-Sakhalinsk, Russia \\ ${ }^{3}$ Moscow State University, Moscow, Russia \\ Email: bragin ivan@mail.ru
}

Received 24 March 2015; accepted 10 July 2015; published 17 July 2015

\begin{abstract}
Different types of groundwater manifestations occurring on modern structure of the Baransky volcano were studied. Volcanic and seismic activity influences strongly on hydrology and hydrochemistry of the groundwater of the watershed of Sernaya river. Three types of fluids have been established: volcanic-heated, steam-heated and mature. Existing model of hydrothermal system of Baransky volcano was confirmed using geothermometry and hydrochemical calculations. Thus Baransky volcano is a complex object with atmospheric recharge, deep diorite body as heat source and thick fractured altered andesitic water reservoir, where different types of water springs can emerge.
\end{abstract}

Keywords

Volcanic Waters, Iturup, Kuril Islands, Hydrogeochemistry

\section{Introduction}

Baransky is a volcanic complex along the Pacific coast consists of an eroded Pleistocene volcano that is capped by a Holocene stratovolcano, located in the center of Iturup island, southern Kuriles $\left(45.097^{\circ} \mathrm{N}, 148.024^{\circ} \mathrm{E}\right)$ (Figure 1). A young summit lava dome is cut by a NW-trending chain of small explosion craters. A group of flank cones farther to the NW with a similar NW-SE orientation is partially surrounded by lava flows from the central crater of the andesitic-dacitic volcano. Lava flows from descended $4-5 \mathrm{~km}$ SE to reach the Pacific Ocean along a broad front. The only historical eruption occurred in 1951, when local inhabitants reported weak explosive activity at the summit. Strong solfataric activity continues from the summit and several flank craters, and the SW flank geothermal field contains hot springs and geysers (Gorshkov, 1967) [1]. An exploration well into a zone of hot water $4.5 \mathrm{~km} \mathrm{SW}$ of the summit of Baransky Volcano (in the Kipyaschiy creek valley) was drilled in the summer of 1991. Drilling was temporarily halted at Baransky in early August, but no casing was 


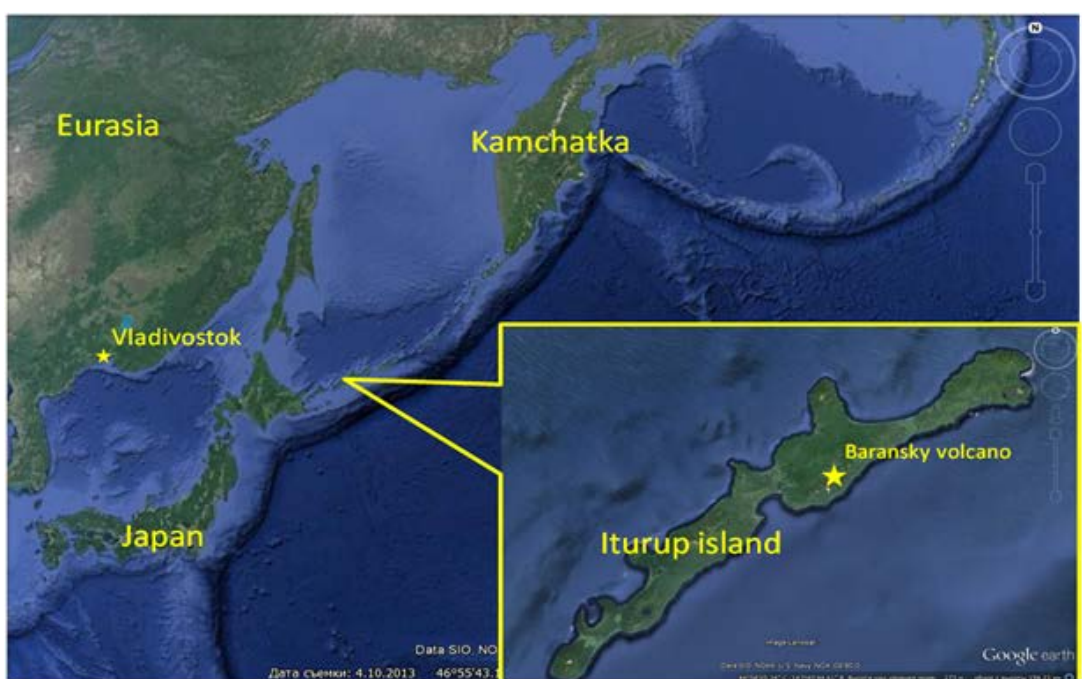

Figure 1. Location of the Baransky volcano. Image from https://earth.google.com/.

installed. Two weeks later, a hydrothermal explosion occurred $50 \mathrm{~m}$ upslope, forming a crater $>10 \mathrm{~m}$ in diameter (Rychagov, 1993) [2].

A mixture of vapor, water, and a large quantity of rock fragments was erupted for several days, destroying vegetation within $50 \mathrm{~m}$. The explosion was believed to have occurred when hot water moved up the borehole after drilling ceased, and escaped through its uncased walls into a permeable fissured zone near the surface. Last eruption occurred on Grozniy volcano (8km on SE), the same volcanic structure. A mixture of vapor, water and rock fragments was erupted for several days. Big stones ( $\sim 1 \mathrm{~m}$ in diameter) were found $\sim 1 \mathrm{~km}$ on West of the volcano Ivan Grozniy. Previously (JKASP-8 Conference, 2014) [3] we stated about total flux from Baransky volcano and it's influence on the environment. Also the aim of that study was to establish observation network and determine background concentrations to detect pre-eruptive period of Baransky. This work is devoted to understanding conditions, which influence variation of chemical composition of waters forming within active volcanoes.

\section{Hydrogeological Settings}

Hydrothermal system is confined to the south-western slope of a young andesitic volcano, located in the center of the Late Pleistocene caldera Kipyaschiy. Caldera Kipyaschiy superimposed on volcano lifting of Grozniy ridge, elongated in the north-east, the Kuril-Kamchatka direction and includes a number of volcano-tectonic structures and the same modern volcanoes: Rebunshiri, Grozniy, Dragon, Machekha, Tebenkov, Baransky (Gorshkov, 1967; Zlobin, 1989) [1] [4]. The base of crosssection of the hydrothermal system down to $1200 \mathrm{~m}$ from the surface is mainly composed of agglomerate tuffs and andesites, andesitic lavas and andesite parusniy suite, $\mathrm{N} 2_{\mathrm{pr}}$.

Power suite of more than $600 \mathrm{~m}$. The rocks sailing suite without apparent angular unconformity lie tufaceous sandstones, gravels and conglomerates, siltstone, pumice tuffs and andesite lava of Lebedinskiy suit: N2-Q1 $1_{\mathrm{bb}}$. Probably, these deposits were formed in relatively isolated shallow pools, lakes or the sea bay, amid intense effusive-explosive activity of Baransky. Thickness reaches $400 \mathrm{~m}$. Upper quanternary lava, tuff and tuff breccias from andesite to andesidacite composition formed, apparently in subaerial conditions with arched-block uplift of Grozniy ridge.

The total thickness of sediments is more than $100-150 \mathrm{~m}$. The latter deposits include modern lavas from andesitic to dacitic composition with 5 - 30 m thickness. Tearing igneous bodies are represented by dikes and sills of andesitic and basaltic composition of 0.5 - $17.0 \mathrm{~m}$ thickness, extrusion of andesidacite composition interstratal lenses (1 - $5 \mathrm{~m}$ ) of diorite-microdiorites. Groups of intrusive bodies, 3 - 6 dikes or sills in each confined to the borders of lithological strata and horizons. Contact of dikes, sills and extrusion are usually brecciated. At depths of $700-1500 \mathrm{~m}$ a roof of a large diorite body is assumed, which is supposed to be a heat source for hydrotherms (Zlobin, 1989; Rychagov, 1993) [2] [4] (Figure 2). 


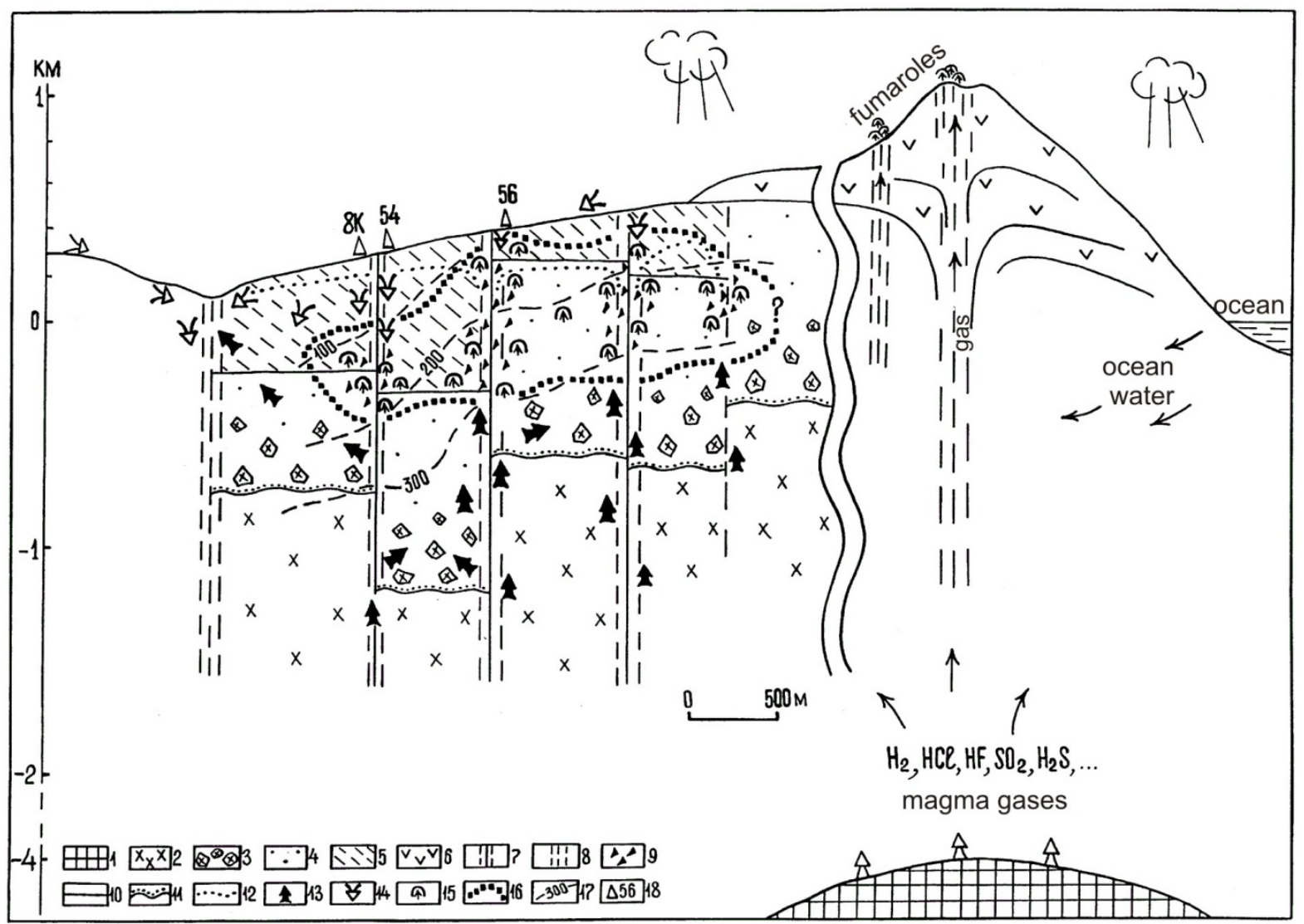

Figure 2. Geological and geochemical model of modern hydrothermal-magmatic system Baransky ((Rychagov, 1993) [2] with changes). 1-the upper edge of the peripheral magma chamber; 2-sub-intrusive diorite-gabbro-diorite; 3-intrusive tuffs (breccias); 4-deposits of Parusniy suite; 5-Lebedinskiy deposits suite; 6-Quaternary andesitic lava; 7-tectonic faults established; 8-the same as alleged; 9-hydrothermal breccias; 10-lithological boundaries; 11-intrusive border; 12-the bottom border of the zone of acid leaching of argillites; 13-upward flow of deep sub-alkaline sodium chloride hydrothermal solutions; 14downdraft flow of meteoric water and acid sulphate hydrothermal fluids; 15-vapor-prevailed zone; 16-mixing area of sodium chloride and sulfate term; 17-isotherm for well logging data; 18-exploration wells and their numbers.

Kipyaschiy creek is $2.5 \mathrm{~km}$ long. It originates on the slopes of the Baransky volcano and flows into the river Sernaya. The Kipyaschiy fault ridge is characterized by maximum heat removal to the surface. Thermo-excurrent fault zones are composed of intensely fractured rocks and various breccias. In the depths of horst there is an active process of metamorphism volcanic, volcano-sedimentary rocks of subvolcanic influenced by high-temperature $\left(300^{\circ} \mathrm{C}-350^{\circ} \mathrm{C}\right)$, fracture-porous sulfide-carbonate-sulphate and sodium chloride, carbon-nitrogen fluids (Rychagov, 1993) [2].

\section{Material and Methods}

We sampled all visible springs and seeps on the watershed of Kipyaschiy creek Samples were collected into acid-washed, high-density polyethylene sampling bottles. Before sampling all water samples were filtered through cellulose filters $(0.45 \mu \mathrm{m})$ and then acidified to $\mathrm{pH}<2$ with an ultrapure nitric acid, excluding samples intended for anion analysis. Water temperature, conductivity and $\mathrm{pH}$ were measured directly in the field (in situ) to avoid changing parameters (Sundaram et al., 2009) [5]. Major elements ( $\mathrm{Na}, \mathrm{K}, \mathrm{Ca}, \mathrm{Mg}$ and $\mathrm{NH}_{4}, \mathrm{NO}_{3}, \mathrm{~F}, \mathrm{Cl}, \mathrm{SO}_{4}$ ) were analyzed by liquid chromatography, with analytical error less than $5 \% . \mathrm{HCO}_{3}$ was determined by titration with a $0.01 \mathrm{~N} \mathrm{HCl}$ solution of $10 \mathrm{ml}$ of a non-filtered non-acidified sample aliquot. Silica concentrations were analyzed by colorimetric photospectrometric methods on diluted samples. Microelements were measured on mass spectrometer with inductive coupled plasma Agilent 7500c, if necessary, samples were pre-acidified to $\mathrm{pH}<$ 2 to prevent fractionation. 


\section{Analytical Results and Discussion}

Thermal water of the Kipyaschiy creek by it's chemical composition is low-mineralized (TDS = 4.0 g/l), chloride-sulphate sodium-calcium ( $\mathrm{SO}_{4}^{2-}-60$ mg-eq.\%, $\mathrm{Cl}^{-}-40$ mg-eq.\%, Ca-40 mg-eq.\%, $\mathrm{Na}^{+}+\mathrm{K}^{+}-37 \mathrm{mg}-\mathrm{eq} . \%$ ), siliceous $\left(\mathrm{H}_{2} \mathrm{SiO}_{3}-326 \mathrm{mg} / \mathrm{l}\right)$, ferrous $\left(\mathrm{Fe}^{2+3+}-12.14 \mathrm{mg} / \mathrm{l}\right)$, acid $(\mathrm{pH}-1.37)$. Waters have meteoric origin $(\mathrm{Chu}-$ daev, 2003) [6], thus surface water penetrate deep enough to heat up and emerge on the surface as thermal spring or boiling pool. Significant concentrations of microcomponents are observed in waters of Kipyaschiy creek (mg/l): Al-84; $\mathrm{Ba}-0.132 ; \mathrm{Be}-0.00057 ; \mathrm{Br}-6.19 ; \mathrm{B}-1.21 ; \mathrm{Fe}^{2+3+}-12.14 ; \mathrm{Li}-0.186 ; \mathrm{Mn}-0.52 ; \mathrm{As}$ $<0.204$; $\mathrm{Pb}-0.28$; which are biologically active. Indicators of organic pollution (mg/l): $\mathrm{O}_{2}-1.26$; DOC -1.9 . This chemical composition of the stream is influenced by hydrothermal fluids (Taran, 2009) [7]. Using $\mathrm{Cl} / \mathrm{SO}_{4}$ correlation all springs that feed the Kipyaschiy creek can be divided into three groups (Table 1):

1) Volcanic-heated waters (on-1, ozk-1). High-temperature acid fluids (TDS = 6 - 10 g/l) chloride-sulphate sodium composition. Usually look like a pool, made inside altered bedrock with deep-blue water bubbling. Walls inside are covered with aluminosilicates precipitated from fluid. $\mathrm{SO}_{4} / \mathrm{Cl}$ ratio $\sim 2.23$.

2) Steam-heated waters (okk-1, kis-1, hkk-1, bsk-1, eksk-1, kpk-1). Moderately acid waters of solfatars, representing the condensed gas fraction of vent gas with sulfate composition and low mineralization (TDS = 1.4 - $2.0 \mathrm{~g} / \mathrm{l}$ ). Usually look like bubbling shallow reservoir with high gas/water ratio. Steam rich with volcanic gases goes through groundwater, acidifying it. Depending on conditions $\mathrm{SO}_{4} / \mathrm{Cl}$ ratio varies from 4 to 6 for cold springs and from 34 to 123 for solfatars. It is significant that we held field experiment of passing solfataric gas through bi-distilled water just before it began boiling. The resulted sample is also put into this group, but it has $\mathrm{SO}_{4} / \mathrm{Cl}$ ratio $\sim 0.18$. It shows that chlorine is more volatile and it's solubility is higher that sulfate and it takes time for water to reach equilibrium with gas.

3) Mature waters (sk-1, fvl-1, kk-1, kin-1). Neutral water mixed ion composition with mineralization about $1 \mathrm{~g} / \mathrm{l}$. This type of waters is usually in equilibrium with host-rock. Outcrop usually has low flow rate, low-temperature, not boiling.

Usage of geothermometers is limited by $\mathrm{pH}$ of studied waters. Usually only mature waters with near neutral

Table 1. Chemical composition and main parameters of waters, originating within Baransky hydrothermal system.

\begin{tabular}{|c|c|c|c|c|c|c|c|c|c|c|c|c|}
\hline Sample ID & \multicolumn{2}{|c|}{$\begin{array}{c}\text { Volcanic-heated } \\
\text { waters }\end{array}$} & \multicolumn{6}{|c|}{ Steam-heated waters } & \multicolumn{4}{|c|}{ Mature waters } \\
\hline $\mathrm{mg} / \mathrm{l}$ & $\begin{array}{l}\text { on-1 } \\
\mathrm{n} / \mathrm{a}\end{array}$ & \begin{tabular}{|c|} 
ozk-1 \\
4100
\end{tabular} & $\begin{array}{c}\text { okk-1 } \\
2010\end{array}$ & $\begin{array}{c}\text { kis-1 } \\
\text { n/a }\end{array}$ & $\begin{array}{c}\text { hkk-1 } \\
219\end{array}$ & $\begin{array}{c}\text { bsk-2 } \\
1390\end{array}$ & $\begin{array}{c}\text { eksk-1 } \\
36\end{array}$ & $\begin{array}{c}\text { kpk-1 } \\
116\end{array}$ & $\begin{array}{c}\text { sk-1 } \\
612\end{array}$ & $\begin{array}{c}\text { fvl-1 } \\
943\end{array}$ & $\begin{array}{c}\text { kk-1 } \\
\mathrm{n} / \mathrm{a}\end{array}$ & $\begin{array}{l}\text { kin-1 } \\
1180\end{array}$ \\
\hline $\mathrm{pH}$ & 1.37 & 1.37 & 1.68 & 2 & 2.95 & 2.98 & 4.3 & 4.58 & 5.81 & 5.87 & 6.23 & 6.97 \\
\hline temp $\quad{ }^{\circ} \mathrm{C}$ & 98 & 100 & 98 & 94.6 & 15 & 24.5 & 89.5 & 14.8 & 56 & 43.2 & 93 & 38 \\
\hline $\mathrm{Na}$ & 140.55 & 136.9 & 9.524 & 9.222 & 5.122 & 7.129 & 3.031 & 9.363 & 81.34 & 116.6 & 22.84 & 135.1 \\
\hline $\mathrm{NH}_{4}$ & 0.8 & 0 & 0.05 & 15.9 & 0.09 & 0.08 & 0.19 & 0.09 & 1.41 & 1.01 & 4.32 & 0 \\
\hline $\mathrm{K}$ & 37.4595 & 42.8025 & 1.5009 & 2.7333 & 0.3558 & 1.1512 & 0.04687 & 1.0823 & 9.809 & 21.249 & 5.017 & 23.3 \\
\hline $\mathrm{Ca}$ & 153.3 & 156.1 & 9.447 & 15.17 & 3.296 & 11.02 & 0.4561 & 9.481 & 62.01 & 81.95 & 20.96 & 93.95 \\
\hline $\mathrm{Mg}$ & 41.3 & 42.3 & 4.123 & 7.6 & 1.504 & 3.433 & 0.1206 & 3.086 & 12.08 & 21.8 & 11.53 & 25.02 \\
\hline $\mathrm{Al}$ & 237.65 & 239.1 & 14.33 & 23.7 & 2.225 & 6.454 & 0.0335 & 0.2709 & 0.143 & 0.089 & 0.289 & 0.067 \\
\hline $\mathrm{B}$ & 7.815 & 8.179 & $\mathrm{n} / \mathrm{a}$ & $\mathrm{n} / \mathrm{a}$ & $\mathrm{n} / \mathrm{a}$ & $\mathrm{n} / \mathrm{a}$ & $\mathrm{n} / \mathrm{a}$ & $\mathrm{n} / \mathrm{a}$ & 0.277 & 1.337 & $\mathrm{n} / \mathrm{a}$ & 1.579 \\
\hline $\mathrm{Fe}$ & 62.95 & 61.16 & 6.66 & 32.08 & 0.4609 & 4.417 & 0.2603 & 0.4468 & 1.067 & 1.314 & 0.105 & 0.402 \\
\hline Mn & 2.112 & 2.138 & 0.1085 & 0.4918 & 0.1007 & 0.155 & 0.0051 & 0.0611 & 0.261 & 0.5376 & 0.743 & 0.554 \\
\hline $\mathrm{F}$ & 0 & 0 & 0.03 & 0 & 0 & 0 & 0 & 0.02 & 0 & 0 & 0 & 0.15 \\
\hline $\mathrm{Cl}$ & 1818 & 1803 & 8.83 & 4.05 & 6.54 & 6 & 5.8 & 9.25 & 43.9 & 139 & 104 & 162 \\
\hline $\mathrm{Br}$ & 1.54 & 1.55 & 0 & 0 & 0 & 0 & 0 & 0.01 & 0.1 & 0.28 & 0.01 & 0.32 \\
\hline $\mathrm{NO}_{3}$ & 2 & 1.142 & 4.63 & 0 & 0.22 & 0 & 61 & 8.56 & 0.67 & 0.48 & 0.06 & 0.25 \\
\hline $\mathrm{SO}_{4}$ & 4025 & 4025 & 713 & 500 & 44.1 & 208 & 1.08 & 39.7 & 52.5 & 180 & 157 & 209 \\
\hline
\end{tabular}


$\mathrm{pH}$ can give good result. Thus we made some calculations using different types of geothermometers for samples sk-1, fvl-1, kk-1 and kin-1. Mg-Li geothermometer (Kharaka \& Mariner, 1989) [8] shows very low temperatures of reservoir $\left(\sim 33^{\circ} \mathrm{C}-39^{\circ} \mathrm{C}\right)$, showing mixing with freshwaters, mainly because of high concentrations of magnesium, caused by bedrock alteration, but not by mixing. Arnorson's Na-K formulas (Arnorson et al, 1983) [9] give high temperatures varying from $247^{\circ} \mathrm{C}$ to $364^{\circ} \mathrm{C}$ depending on site, caused by high concentrations of potassium showing deep water-rock interactions at high temperatures. Maybe main deep reservoir possess such high temperatures $\left(\sim 300^{\circ} \mathrm{C}\right)$, it is possible. Na-Li geothermometer (Kharaka, Lico \& Lax, 1982) [10] show intermediate values $\left(133^{\circ} \mathrm{C}-144^{\circ} \mathrm{C}\right)$ for warm (surface temperatures $38^{\circ} \mathrm{C}-56^{\circ} \mathrm{C}$ ) springs: ck-1, fvl-1 and kin- 1 and rather high value for boiling kk-1 $\left(208^{\circ} \mathrm{C}\right)$, which is also possible and should be studied later.

As conclusion we can point out that hydrothermal system of Baransky volcano is a complex object with atmospheric recharge, deep diorite body as heat source and thick fractured altered andesitic water reservoir, where different types of water springs can emerge.

\section{Acknowledgements}

This work was done under support of grant by Russian Scientific Fund 14-17-00415.

\section{References}

[1] Gorshkov, G.S. (1967) Volcanism of Kuril Islands Arc. Moscow, Nauka.

[2] Rychagov, S.N. (1993) Hydrothermal System of the Baransky Volcano. Volcanology and Seismology, 2, 59-74.

[3] JKASP-8 Conference (2014) Hydrochemical Fluxes from Baransky Volcano, Iturup, Kuril Islands. http://hkdrcep.sci.hokudai.ac.jp/map/jkasp2014/pdf/R48.pdf

[4] Zlobin, T.K. (1989) Lithosphere Structure near Iturup Island (Seismic Data). Journal of Pacific Geology, 3, 33-41.

[5] Sundaram, B., Feitz, A., de Caritat, P., Plazinska, A., Brodie, R., Coram, J. and Ransley, T. (2009) Groundwater Sampling and Analysis. A Field Guide. Geoscience, Australia.

[6] Chudaev, O.V. (2003) Composition and Origin of the Recent Hydrothermal Systems of the Far East Russia. Vladivostok, Dalnauka.

[7] Taran, Y.A. (2009) Geochemistry of Volcanic and Hydrothermal Fluids and Volatile Budget of the Kamchatka-Kuril Subduction Zone. Geochimica et Cosmochimica Acta, 73, 1067-1094. http://dx.doi.org/10.1016/j.gca.2008.11.020

[8] Kharaka, Y.K. and Mariner, R.H. (1989) Chemical Geothermometers and Their Application to Formation Waters from Sedimentary Basins. In: Naeser, N.D. and McCulloch, T.H., Eds., Thermal History of Sedimentary Basins: Methods and Case Histories (pp. 99-117), Springer-Verlag, New York. http://dx.doi.org/10.1007/978-1-4612-3492-0_6

[9] Arnorsson, S., Gunnlaugsson, E. and Svavarsson, H. (1983) The Chemistry of Geothermal Waters in Iceland III. Chemical Geochemistry in Geothermal Investigations. Geochimica et Cosmochimica Acta, 47, 567-577. http://dx.doi.org/10.1016/0016-7037(83)90278-8

[10] Kharaka, Y.K., Lico, M.S. and Lax, L.M. (1982) Chemical Geothermometers Applied to Formation Waters, Gulf of Mexico and California Basins. Bulletin of the American Association of Petroleum Geologists, 66, 588. 